\title{
Analisis Biaya Diferensial Dalam Pengambilan Keputusan Membeli Atau Memproduksi Sendiri Pada UD. Nabila Jepara Meubel Dan UD. Jepara Furniture
}

\author{
Oleh: \\ Astyta Permata Simbawa1 \\ Jullie Sondakh \\ Heince Wokas
}

\author{
Fakultas Ekonomi Dan Bisnis \\ Universitas Sam Ratulangi Manado \\ Email: ${ }^{1}$ astytasimbawa@gmail.com
}

\begin{abstract}
The situation and current economic conditions impacted the intense competition among the companies of the world. Therefore, the company management needs to create a policy that refers to the creation of the efficiency and effectiveness of the company performance. The management needs the information as a basis for decision making, one of the types of information needed is the management of differential cost analysis information. In this observation, differential cost analysis is used to help management firm in the face of some of the alternatives that exist to make a decision to buy or produce its own by using half-finished wood as a raw material. The purpose of this observation was to analyze the differential costs in the decision to buy or produce own staple at UD Nabila Jepara Furniture and UD Jepara Furniture. The analysis method used in this research is descriptive method. Results of the assessment showed differential costs right a decision has been taken by management of UD Nabila Jepara Furniture and UD Jepara Furniture is producing its own because of differential gain a higher profit than buying from outside.
\end{abstract}

Keywords: Cost differential, To buy or to produce its own.

\section{PENDAHULUAN}

Era globalisasi sekarang ini sangat berdampak pada ketatnya persaingan di antara perusahaan-perusahaan dunia. Persaingan tersebut terjadi di sektor perekonomian baik industri, perdagangan maupun jasa. Kesuksesan dalam persaingan akan dapat dipenuhi apabila perusahaan bisa menciptakan dan mempertahankan pelanggan.Begitu hebatnya arus globalisasi melanda dunia ini, maka tidak ada satu negara pun yang tidak terpengaruh oleh perkembangan ekonomi global. Dengan keadaan ekonomi dunia yang tidak konsisten tersebut maka perusahaan dituntut untuk terus melakukan perubahan ke arah yang lebih baik agar dapat bertahan di lingkungan persaingan yang semakin ketat. Oleh karena itu pihak manajemen perusahaan perlu membuat suatu kebijakan yang mengacu pada terciptanya efisiensi dan efektifitas kinerja. Salah satu usaha untuk meningkatkan efisiensi dan efektif perusahaan adalah dengan memproduksi barang yang berkualitas.

Untuk dapat melakukan fungsinya, pihak manajemen membutuhkan informasiinformasi sebagai dasar pengambilan keputusan untuk kepentingan perusahaan. Salah satu jenis informasi yang dibutuhkan oleh manajemen sebagai dasar perencanaan dan pengambilan keputusan adalah informasi akuntansi diferensial (differential accounting information). Informasi akuntansi diferensial adalah suatu informasi akuntansi yang menyajikan perbedaan aktiva, pendapatan dan biaya dalam alternatif tindakan tertentu dibandingkan dengan altenatif tindakan lain. 
Analisis biaya diferensial membantu manajemen menghadapi empat macam pengambilan keputusan dalam jangka pendek, yaitu membeli atau memproduksi sendiri, menjual atau memproses lebih lanjut suatu produk, menghentikan atau melanjutkan produksi produk tertentu atau kegiatan usaha suatu bagian perusahaan, menerima atau menolak pesanan khusus.

Salah satu keputusan yang perlu diambil dalam perencanaan pada setiap alternatif adalah membeli atau memproduksi sendiri suatu komponen bahan baku. Sebelum membuat keputusan, pihak manajemen membandingkan alternatif-alternatif yang sudah ada. Setiap alternatif yang dibandingkan dengan altenatif lainnya, tentu dilihat mana biaya yang lebih meringankan perusahaan tetapi hasilnya akan lebih besar atau sekurang-kurangnya sama.

UD. Nabila Jepara Meubel dan UD. Jepara Furniture adalah perusahaan-perusahaan yang bergerak di bidang furniture dan menghasilkan berbagai jenis produk rumah tangga seperti meja, tempat duduk, lemari dan sebagainya. Untuk memproduksi furniture-furniture tersebut UD. Nabila Jepara Meubel dan UD. Jepara Furniture membutuhkan atau membeli bahan setengah jadi dalam hal ini bahan utamanya adalah kayu dengan kualitas yang bermutu tinggi dari pihak ketiga. Kayu yang di beli dari pihak ketiga sudah diukir terlebih dahulu sesuai dengan perusahaan inginkan kemudian kayu tersebut dikirim dan proses selanjutnya dilakukan pada perusahaan UD. Nabila Jepara Meubel dan UD. Jepara Furniture yaitu proses finishing dan dirakit kembali untuk mendapatkan design sesuai dengan permintaan pasar.

Mengetahui penerapan biaya diferensial dalam pengambilan keputusan membeli atau memproduksi sendiri pada UD. Nabila Jepara Meubel Dan UD. Jepara Furniture.

\section{TINJAUAN PUSTAKA}

Amir (2008:7) akuntansi adalah pencatatan, pengklasifikasian, dan pengikhtisaran peristiwa-peristiwa ekonomi dengan cara yang logis yang bertujuan menyediakan informasi keuangan untuk mengambil keputusan. Arfan (2010:2) akuntansi suatu disiplin jasa yang mampu memberikan informasi yang relevan dan tepat waktu mengenai masalah keuangan perusahaan guna membantu pemakai internal dan eksternal dalam proses pengambilan keputusan ekonomi

Horngren (2008:2) Akuntansi manajemen adalah proses mengukur, menganalisis dan melaporkan informasi keuangan dan non keuangan yang membantu manajer membuat keputusan guna mencapai tujuan organisasi. Dapat diambil kesimpulan bahwa akuntansi manajemen merupakan proses memasok informasi yang relevan kepada manajer dan tenaga kerja, baik informasi keuangan maupun non keuangan, untuk pengambilan keputusan, pengalokasian sumber daya dan pemonitoran, pengevaluasian dan pemberian imbalan terhadap kinerja.

Mursyidi (2008:11) menjelaskan akuntansi biaya merupakan suatu sistem dalam rangka mencapai tujuan utama yaitu menentukan harga pokok produk atau jasa, mengendalikan biaya, dan memberikan informasi sebagai dasar pengambilan keputusan. Widilestariningtyas (2012:10) menjelaskan akuntansi biaya adalah proses pencatatan, penggolongan, peringkasan, dan penyajian biaya pembuatan dan penjualan produk atau jasa, dengan cara-cara tertentu, serta penafsiran terhadapnya.

Akuntansi diferensial merupakan informasi akuntansi yang menyajikan informasi mengenai taksiran pendapatan, biaya dan atau aktiva yang berbeda jika suatu tindakan tertentu dipilih, dibandingkan dengan alternatif tindakan lain.

Pengambilan keputusan (decision making) adalah memilih salah satu diantara berbagai alternatif tindakan yang ada. Krismiaji (2011:212) keputusan membeli atau membuat sendiri dihadapi oleh manajemen terutama dalam perusahaan yang produknya terdiri dari berbagai komponen dan yang memproduksi berbagai jenis produk, pengambilan keputusan itu sendiri 
dapat dipandang dari dua sisi yaitu perusahaan dalam kondisi memproduksi sendiri dan mempertimbangkan untuk membeli dari luar dan perusahaan membeli dan mempertimbangkan untuk memproduksi sendiri.

Rantung (2014) dengan judul Penerapan Biaya Diferensial Dalam Pengambilan Keputusan Membeli atau Memproduksi Sendiri Pada RM. Pangsit Tompaso. Tujuan penelitian ini untuk mengetahui penerapan biaya diferensial dalam pengambilan keputusan membeli atau memproduksi sendiri. Penelitian ini dilakukan dengan metode deskriptif. Hasil penelitian ini menunjukkan keputusan yang tepat yang dapat diambil manajemen adalah memproduksi sendiri karena mendapat laba diferensial lebih rendah dibandingkan membeli dari luar. Persamaan dalam penelitian ini adalah menganalisis biaya diferensial dalam kaitannya dengan pengambilan keputusan untuk membeli atau memproduksi sendiri. Perbedaan dalam penelitian ini yaitu objek penelitian yang berbeda.

Tumbol (2014) dengan judul Analisis Dengan Menggunakan Informasi Akuntansi Diferensial Dalam Pengambilan Keputusan Membeli Atau Membuat Sendiri Bakso Pasuruan. Tujuan penelitian ini adalah untuk mengetahui dan menganalisis penggunaan informasi akuntansi diferensial dalam pengambilan keputusan membeli atau membuat sendiri bakso.penelitian ini dilakukan dengan metode penelitian deskriptif. Hasil penelitian ini menunjukkan keputusan yang diambil oleh pihak bakso pasuruan adalah membuat sendiri bakso karena biaya yang dikeluarkan lebih kecil atau lebih hemat jika dibandingkan dengan membeli dari pemasok. Persamaan dalam penelitian ini adalah menggunakan metode deskriptif serta pengambilan keputusan yang sama. Perbedaan dalam penelitian ini yaitu objek penelitian yang berbeda.

Tampubolon (2013) dengan judul Penerapan Informasi Diferensial Dalam Pengambilan Keputusan Membeli Atau Membuat Sendiri Produk Setengah Jadi Pada UD. Berkat Anugerah. Tujuan penelitian ini adalah mengetahui dan menganalisis penerapan informasi akuntansi diferensial dalam proses pengambilan keputusan membeli atau membuat sendiri. Penelitian ini dilakukan dengan metode deskriptif. Hasil penelitian ini menunjukkan perusahaan UD. Berkat Anugerah memerlukan informasi yang dapat mengurangi ketidakpastian, salah satu informasi yang diperlukan akuntansi diferensial. Persamaan dalam penelitian ini adalah menganalisis biaya diferensial dalam pengambilan keputusan. Perbedaan dalam penelitian ini yaitu objek penelitian yang berbeda.

\section{METODE PENELITIAN}

\subsection{Data}

Penelitian ini merupakan penelitian bersifat deskriptif yang menggambarkan dan menginterpretasikan objek sesuai dengan apa adanya serta untuk memperoleh gambaran secara sistematis tentang fakta-fakta yang berkaitan dengan keadaan dan kejadian sekarang.

Tempat penelitian penulis dilaksanakan pada UD. Nabila Jepara Meubel yang beralamat J1. Sungai Musi Kelurahan Singkil 1 Manado dan UD. Jepara Furniture yang beralamat Singkil Lingkungan 1 sedangkan waktu penelitian di mulai sejak Oktober-November 2014 dan pada bulan Maret 2015. Dalam penelitian ini, penulis memilih dua objek perusahaan pada UD.Nabila Jepara Meubel dan UD. Jepara Furniture karena perusahaan-perusahaan tersebut merupakan salah satu dari banyak perusahaan yang memproduksi produk-produk yang berkualitas dan memiliki nilai jual di masyarakat luas.

Adapun langkah-langkah yang dilakukan dalam pelaksanaan penelitian ini yaitu:

1. Permohonan mengadakan penelitian.

2. Pengumpulan data.

3. Pengolahan data.

Untuk memperoleh data yang diperlukan dalam penelitian ini yaitu: 
1. Penelitian lapangan berupa wawancara dan pengamatan langsung.

2. Dokumentasi

Kuncoro (2009:145) menjelaskan bahwa, Jenis data dapat dibagi menjadi:

1. Data Kualitatif merupakan data yang disajikan secara deskriptif atau bentuk uraian yang berupa gambaran umum perusahaan dan struktur organisasi.

2. Data Kuantitatif merupakan data yang disajikan dalam bentuk angka, berupa data-data biaya produksi dan data banyaknya jumlah produksi.

Kuncoro (2009:148) menyatakan bahwa, dilihat dari sumbernya maka data yang digunakan dalam penelitian ini adalah data primer dan data sekunder.

1. Data Primer

Data primer merupakan data penelitian yang diperoleh dengan survei lapangan yang menggunakan semua metode pengumpulan data original.

2. Data Sekunder

Data sekunder merupakan data yang dikumpulkan oleh lembaga pengumpulan data dan dipublikasikan kepada masyarakat pengguna data.

\subsection{Definisi Operasional}

Untuk menyamakan presepsi dan agar tidak terjadi kesalahan dalam mengintepretasikan dalam penelitian ini, maka perlu dibahas beberapa definisi operasional yang relevan dipakai dalam menyusun skripsi ini, antara lain sebagai berikut:

1. Informasi akuntansi diferensial merupakan informasi tentang bagaimana biaya, penghasilan dan aktiva akan berbeda jika suatu tindakan di ambil.

Pengambilan keputusan adalah suatu cara yang digunakan untuk memberikan suatu pendapat yang dapat menyelesaikan suatu masalah dengan cara atau teknik tertentu agar dapat diterima oleh semua pihak

\subsection{Metode Analisis Data}

Metode analisis data yang digunakan adalah metode deskriptif. Metode ini merupakan suatu metode yang bertujuan menguraikan, membandingkan, memberikan gambaran perusahaan dan menerangkan suatu data kemudian dianalisis sehingga dapat membuat kesimpulan sesuai dengan informasi dan data yang telah ada.

\section{HASIL ANALISIS DAN PEMBAHASAN \\ 4.1.Hasil Analisis}

UD. Nabila Jepara Meubel adalah sebuah perusahaan meubel yang berdiri sejak tahun 1998, awalnya perusahaan ini hanya home industry saja tetapi seiring berkembangnya teknologi dan kualitas produk yang dihasilkan semakin variatif membuat perusahaan ini telah memperluas tempat produksi. Perusahaan ini melayani kebutuhan yang diperlukan masyarakat akan produk furniture rumah tangga seperti meja, kursi, lemari, tempat tidur dan bisa di pesan sesuai dengan keinginan masyarakat, dan sekarang perusahaan ini telah membuka toko sendiri yang berlokasi di kairagi dengan nama toko Nabila Meubel. Produk furniture perusahaan ini telah banyak digunakan di perumahan, hotel maupun cafe yang di seluruh daerah Sulawesi Utara bahkan sampai ke kawasan Timur Indonesia.

UD. Jepara Furniture merupakan perusahaan meubel yang berdiri sejak tahun 2000 dimana perusahaan ini melayani berbagai macam kebutuhan yang diperlukan oleh seluruh lapisan masyarakat yang ada di Indonesia. Produk yang di tawarkan tentunya memiliki kualitas yang tinggi dan berbahan dasar kualitas yang tinggi pula. Perusahaan ini menawarkan berbagai macam furniture yang dapat masyarakat pesan sesuai dengan keinginan masyarakat dan tentunya perusahaan menjamin barang tersebut hingga sampai tempat tujuan.

UD. Nabila Jepara Meubel dan UD. Jepara Furniture merupakan perusahaan manufaktur yang bergerak dibidang pembuatan berbagai macam peralatan furniture yang berhubungan dengan peralatan rumah tangga maupun perkantoran. Pada umumnya sebuah perusahaan 
meubel membeli bahan baku setengah jadi dari pemasok luar dan kemudian memproses kembali menjadi produk jadi. Berdasarkan informasi yang diperoleh dari UD. Nabila Jepara Meubel dan UD. Jepara Furniture, perusahaan ini membeli produk setengah jadi dari luar dan kemudian untuk lebih memudahkan perhitungan maka diperlukan penggolongan biaya yang dapat berguna bagi kedua perusahaan ini dalam pengambilan keputusan membeli atau memproduksi sendiri.

Tabel 1. Membeli Dari Luar Periode 2014

\begin{tabular}{llllll}
\hline \multicolumn{2}{l}{ Biaya Produksi } & Ket. & $\begin{array}{l}\text { Jumlah } \\
\text { Unit }\end{array}$ & Harga per Unit & Total \\
\hline Bahan & Baku & Kayu & 125 set & Rp. 3.600 .000 & Rp. \\
Langsung & & & & & 450.000 .000 \\
\hline TOTAL & & & & & Rp. \\
& & & & $\mathbf{4 5 0 . 0 0 0 . 0 0 0}$ \\
\hline
\end{tabular}

Sumber: UD. Nabila Jepara Meubel, 2014

Tabel 1 pada perusahaan UD. Nabila Jepara Meubel mendapatkan tawaran untuk membeli produk setengah jadi dari pemasok luar. Setiap bulannya perusahaan dapat membeli 10 set produk setengah jadi dengan harga persetnya Rp. 3.600.000. Selama tahun 2014 perusahaan membeli 125 set produk setengah jadi yang dibeli dari beberapa toko meubel dengan total keseluruhannya sebesar Rp. 450.000.000.

Tabel 2. Membeli Dari Luar Periode 2014

\begin{tabular}{llllll}
\hline Biaya Produksi & \multirow{2}{*}{ Ket. } & $\begin{array}{l}\text { Jumlah } \\
\text { Unit }\end{array}$ & Harga per Unit & Total \\
\hline Bahan Baku & Kayu & 100 set & Rp. 3.000 .000 & Rp. \\
Langsung & & & & 300.000 .000 \\
\hline TOTAL & & & & Rp. \\
& & & & $\mathbf{3 0 0 . 0 0 0 . 0 0 0}$ \\
\hline
\end{tabular}

Sumber: UD. Jepara Furniture, 2014

Tabel 2 pada perusahaan UD. Jepara Furniture mendapatkan tawaran untuk membeli produk setengah jadi dari pemasok luar. Setiap bulannya perusahaan dapat membeli 8 set produk setengah jadi kayu dengan harga persetnya kurang lebih Rp. 3.000.000. Selama tahun 2014 perusahaan membeli 100 set produk setengah jadi dengan total keseluruhannya sebesar Rp. 300.000.000.

Alternatif selain membeli dari luar adalah dengan memproduksi sendiri. Biaya memproduksi sendiri tersebut dapat dilihat dari tabel di bawah ini: 
Tabel 3. Biaya Memproduksi Sendiri Periode 2014

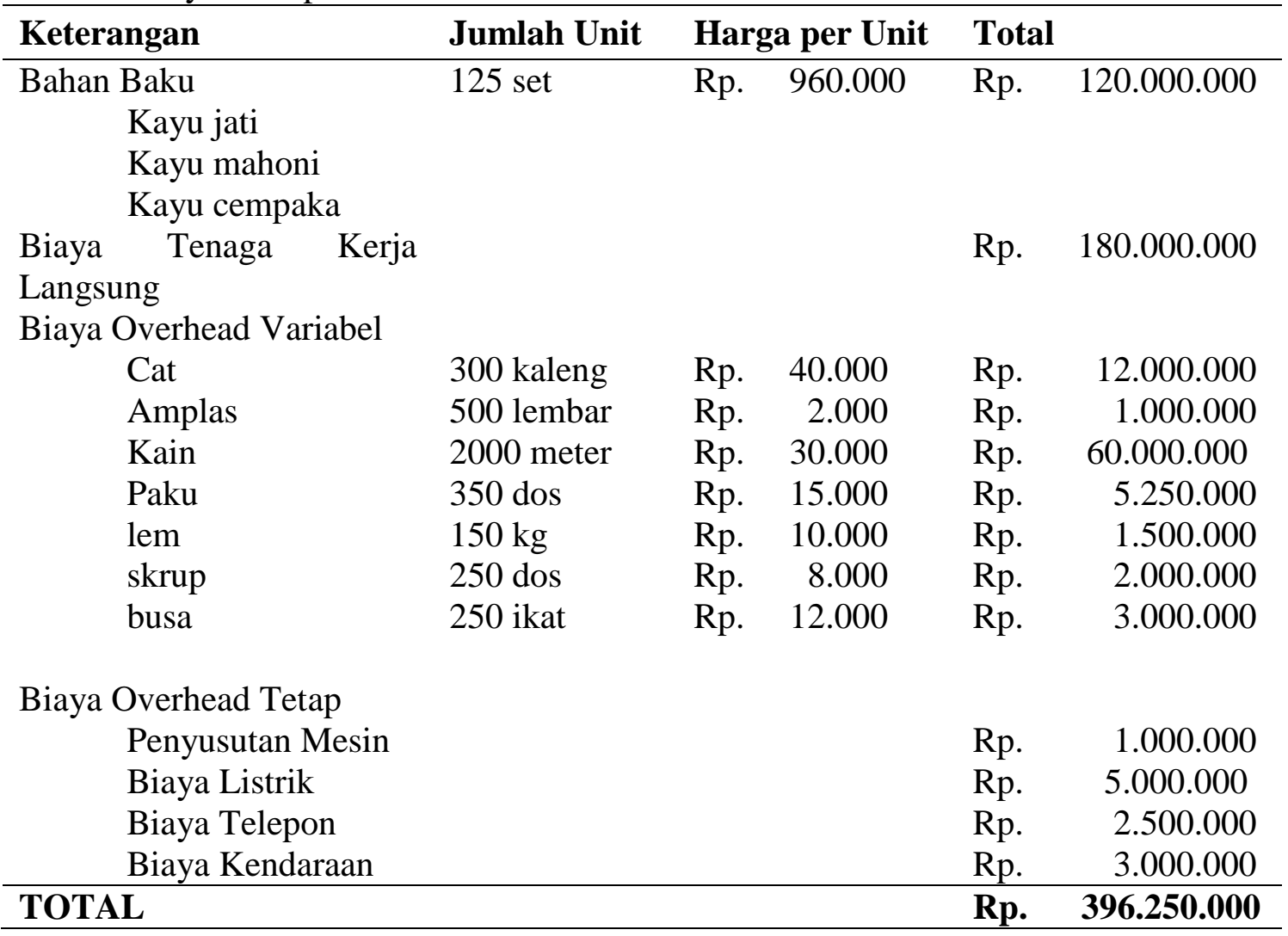

Sumber : UD. Nabila Jepara Meubel, 2014

Tabel 3 untuk memenuhi penjualan pada tahun 2014 Biaya bahan baku yang dikeluarkan perusahaan untuk memproduksi bahan baku utamanya, dimana untuk mendapatkan produk kursi, lemari, meja atau tempat tidur perusahaan menggunakan kayu yang berkualitas baik seperti kayu jati, mahoni dan cempaka sehingga perusahaan harus memproduksi 125 set kayu dengan harga per setnya Rp. 960.000 total biaya keseluruhannya Rp. 120.000.000. Biaya tenaga kerja langsung 10 orang pegawai setiap pegawai digaji Rp. 1.500.000 per bulannya, total untuk biaya tenaga kerja langsung selama 1 tahun sebesar Rp. 180.000.000. Biaya overhead variabel dari bahan baku tidak langsung yang terdiri dari cat,amplas, kain, paku, lem, skrup dan busa total keseluruhannya Rp. 84.750.000. Dan untuk biaya overhead tetap yang terdiri dari penyusutan mesin, biaya listrik, biaya kendaraan dan biaya telepon jumlah keseluruhannya Rp. 11.500.000. 
Tabel 4. Biaya Memproduksi Sendiri Periode 2014

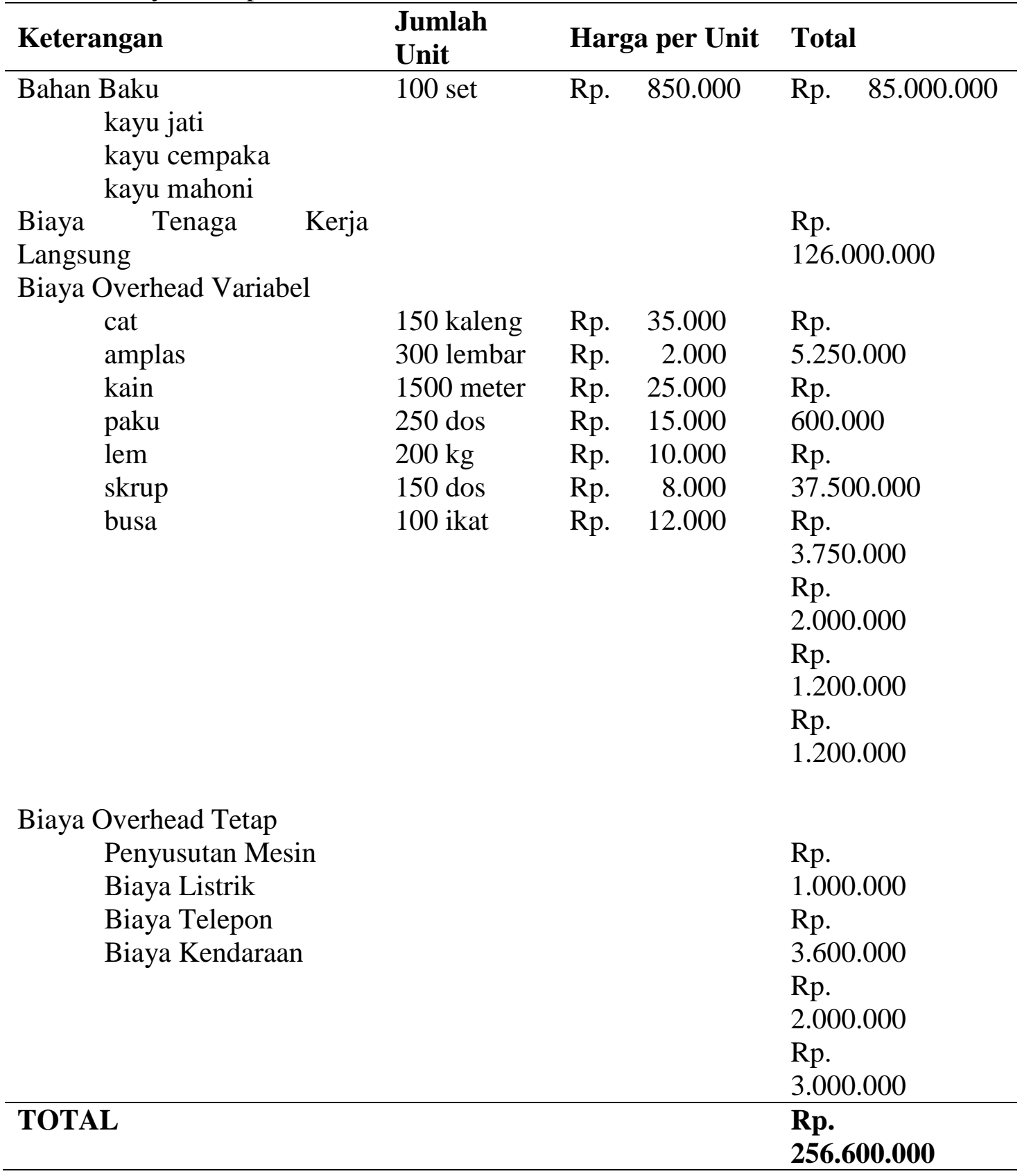

Sumber :UD. Jepara Furniture, 2014

Tabel 4 untuk memenuhi penjualan pada UD. Jepara Furniture tahun 2014 biaya bahan baku yang harus dikeluarkan perusahaan untuk memproduksi kayu sebanyak 100 set dengan harga per setnya Rp. 850.000 sehingga total keseluruhannya sebesar Rp. 85.000.000. Biaya tenaga kerja langsung 7 orang pegawai setiap pegawai digaji Rp. 1.500 .000 per bulannya, total untuk biaya tenaga kerja langsung selama 1 tahun sebesar Rp. 126.000.000. Biaya overhead variabel dari bahan baku tidak langsung yang terdiri dari cat, amplas, kain, paku, lem, skrup, busa total keseluruhannya Rp. 51.500.000. Dan untuk biaya overhead tetap yang terdiri dari penyusutan mesin, biaya listrik dan biaya telepon dan biaya kendaraan jumlah keseluruhannya Rp. 9.600 .000 


\subsection{Pembahasan}

Setiap perusahaan menjalankan usahanya tidak luput dari berbagai macam masalah. Tantangan yang dihadapi tidak dapat diabaikan begitu saja karena secara langsung ataupun tidak langsung dapat menghambat pencapaian tujuan perusahaan. Oleh karena itu sangat diperlukan jalan keluar yang tepat atas masalah yang dihadapi. Perusahaan UD. Nabila Jepara Meubel dan perusahaan UD. Jepara Furniture tidak terlepas dari masalah dalam menjalankan operasinya. Salah satu diantaranya membeli atau memproduksi sendiri produk setengah jadi. Dalam penyelesaian masalah ini diperlukan pertimbangan dan perhitungan dari manajemen agar keputusan yang diambil tidak merugikan perusahaan.

Dalam upaya untuk memperoleh laba yang optimal dari hasil produksinya, maka pihak manajemen perusahaan perlu mengelolah kegiatan produksinya secara efektif dan efisien khususnya pada proses produksi produk setengah jadi sehingga dapat dijadikan sebagai alat pengambilan keputusan. Informasi akuntansi diferensial yang ada di perusahaan bukanlah semata-mata sebagai bahan pengambilan keputusan akan tetapi lebih banyak berperan untuk mengumpulkan data informasi relevan dan menganalisa informasi tersebut. Dengan semakin meningkatnya persaingan dan untuk mendapatkan keuntungan yang optimal maka perusahaan mencoba menganalisis masalah ini.

Dalam memecahkan masalah yang dihadapi ini terdapat dua alternatif yang dapat dipilih oleh perusahaan yaitu dengan cara memproduksi sendiri produk setengah jadi atau membeli produk setengah jadi dari pemasok luar.

Dalam lingkup manajemen analisis ini bisa digunakan dalam pengambilan keputusan memproduksi atau membeli dari pihak luar. Selisih antara membeli atau memproduksi sendiri produk setengah jadi tersebut dapat dilihat dari tabel perbandingan di bawah ini:

Tabel 5. Perbandingan Membeli Atau Memproduksi Sendiri Periode 2014

\begin{tabular}{|c|c|c|c|c|}
\hline \multirow{2}{*}{$\begin{array}{c}\text { KETERAN } \\
\text { GAN }\end{array}$} & \multicolumn{2}{|c|}{$\begin{array}{l}\text { UD. NABILA JEPARA } \\
\text { MEUBEL }\end{array}$} & \multicolumn{2}{|c|}{ UD. JEPARA FURNITURE } \\
\hline & $\begin{array}{l}\text { Membeli } \\
\text { Dari Luar }\end{array}$ & $\begin{array}{c}\text { Memproduksi } \\
\text { Sendiri }\end{array}$ & $\begin{array}{l}\text { Membeli } \\
\text { Dari Luar }\end{array}$ & $\begin{array}{l}\text { Memproduksi } \\
\text { Sendiri }\end{array}$ \\
\hline Bahan Baku & & Rp. & & $\mathrm{Rp}$ \\
\hline Tenaga Kerja & & 120.000 .000 & & 85.000 .000 \\
\hline BOP & & Rp. & & Rp. 126.000 .000 \\
\hline Variabel & & $\begin{array}{l}180.000 .000 \\
\text { Rp. } \\
84.750 .000\end{array}$ & & Rp. 51.500 .000 \\
\hline Harga Beli & $\begin{array}{l}\text { Rp. } \\
450.000 .000\end{array}$ & & $\begin{array}{l}\text { Rp. } \\
300.000 .000\end{array}$ & \\
\hline BOP Tetap & & $\begin{array}{l}\text { Rp. } \\
11.500 .000\end{array}$ & & $\begin{array}{l}\text { Rp. } \\
9.600 .000\end{array}$ \\
\hline $\begin{array}{l}\text { Total Biaya } \\
\text { Diferensial }\end{array}$ & $\begin{array}{l}\text { Rp. } \\
450.000 .000\end{array}$ & $\begin{array}{l}\text { Rp. } \\
396.250 .000\end{array}$ & $\begin{array}{l}\text { Rp. } \\
300.000 .000\end{array}$ & $\begin{array}{l}\text { Rp. } \\
272.100 .000\end{array}$ \\
\hline $\begin{array}{l}\text { Laba } \\
\text { Diferensial }\end{array}$ & & Rp. 53.750.000 & & Rp. 27.900 .000 \\
\hline
\end{tabular}

Sumber: Data Hasil Olahan, 2014

Data hasil perbandingan pada UD. Nabila Jepara Meubel untuk biaya membeli dari luar total biaya diferensial sebesar Rp. 450.000.000, dan jika perusahaan memproduksi sendiri total biaya diferensial sebesar Rp. 396.250.000 sehingga mendapat laba diferensial sebesar Rp. 53.750.000. Pada perusahaan UD. Jepara Furniture biaya membeli dari luar total biaya 
diferensial sebesar Rp. 300.000.000, dan jika perusahaan memproduksi sendiri sebesar Rp. 272.100.000 sehingga pada perusahaan ini mendapatkan laba diferensial sebesar Rp. 27.900.000.

Hasil analisis biaya diferensial pada UD. Nabila Jepara Meubel dan UD. Jepara Furniture menyimpulkan bahwa tujuan utama perusahaan ini adalah untuk meningkatkan laba. Untuk mencapai tujuan tersebut maka manajer harus mengambil keputusan yang tepat guna meningkatkan laba perusahaan. Berdasarkan penelitian di atas maka hasil perbandingan membeli dari luar atau memproduksi sendiri produk setengah jadi adalah keputusan memproduksi sendirilah yang lebih tepat diambil karena dapat menghemat biaya dibandingkan membeli dari luar.

\section{KESIMPULAN}

Berdasarkan analisis diatas, maka dapat diambil kesimpulan yaitu: penggunaan informasi akuntansi diferensial sangat bermanfaat terhadap manajemen UD. Nabila Jepara Meubel dan UD. Jepara Furniture dalam memperoleh informasi yang dibutuhkan untuk dapat membandingkan keputusan manakah yang lebih menguntungkan di antara membeli atau memproduksi sendiri produk setengah jadi. Perbandingan perhitungan biaya-biaya yang dikeluarkan oleh kedua alternatif membeli atau memproduksi sendiri produk setengah jadi menunjukkan bahwa memproduksi sendiri adalah keputusan yang tepat karena mendapatkan laba diferensial yang lebih hemat dari pada membeli dari luar. Dengan menggunakan informasi diferensial telah diketahui bahwa alternatif memproduksi sendiri dapat menghemat biaya produksi kayu.

Adapun saran yang dapat penulis berikan sebagai bahan pertimbangan pada perusahaan-perusahaan ini yaitu sebaiknya usaha pada UD. Nabila Jepara Meubel dan usaha pada UD. Jepara Furniture memproduksi sendiri produk setengah jadi mengingat biaya yang dikeluarkan lebih rendah dari pada membeli produk setengah jadi dari pihak luar karena dapat melakukan penghematan biaya dan juga lebih menguntungkan.

\section{DAFTAR PUSTAKA}

Amir, Randal, Mark, Alvin. (2008). Jasa Audit dan Assurance. Salemba Empat. Jakarta.

Arfan Ikhsan. (2010). Akuntansi Keperilakuan. Edisi Kedua. Salemba Empat. Jakarta.

Depdikbud. (2007). Kamus Besar Bahasa Indonesia. Jakarta. Balai Pustaka.

Hansen, Mowen. 2009. Akuntansi Manajerial. Edisi Kedelapan. Salemba Empat. Jakarta.

Horngren, Datar, Foster. (2008). Akuntansi Biaya Dengan Penekanan Manajerial. Edisi Keduabelas. Erlangga. Jakarta.

Kamaruddin. Ahmad. (2009). Akuntansi Manajemen. Edisi Revisi Ke Enam. Raja Grafindo Persada. Jakarta.

Krismiaji. (2011). Akuntansi Manajemen. Edisi Kedua. UPP STIM-YKPN. Yogyakarta.

Kuncoro. Mudrajad. (2009). Metode Riset Untuk Bisnis dan Ekonomi. Edisi Ketiga. Erlangga. Jakarta.

Mulyadi. (2012). Akuntansi Biaya. Edisi Kelima. UPP STIM-YKPN. Yogyakarta.

Mursyidi. (2008). Akuntansi Biaya. Edisi Pertama. Refika Aditama. Bandung.

Rantung, Dewinta, (2014). Penerapan Biaya Diferensial Dalam Pengambilan Keputusan Membeli Atau Memproduksi Sendiri Pada Rm. Pangsit Tompaso. Jurnal EMBA ISSN 2303-1174

Vol.2 http://ejournal.unsrat.ac.id/index.php/emba/article/viewFile/5067/4585. Diakses $21 \mathrm{Mei}$ 2014

Soemarso. (2009). Akuntansi Suatu Pengantar. Edisi Kelima. Salemba Empat. Jakarta. 
Tampubolon. Phamela. (2013). Penerapan Informasi Akuntansi Diferensial Dalam Pengambilan Keputusan Membeli Atau Membuat Sendiri Produk Setengah Jadi Pada UD. Berkat Anugerah. Jurnal Riset Akuntansi GOING CONCERN ISSN 1907-9737 Vol.8.

http://portalgaruda.org.

Tumbol, Wanda,. (2014). Analisis Dengan Menggunakan Informasi Akuntansi Diferensial Dalam Pengambilan Keputusan Membeli Atau Membuat Sendiri Bakso Pada Bakso Pada Bakso Pasuruan. Jurnal EMBA ISSN 2303-1174 Vol.2

http://ejournal.unsrat.ac.id/index.php/emba/article/viewFile/.../4333. Diakses 21 Mei 2014.

Widilestariningtyas, Ony, Anggraini, Sri, Firdaus, Doni. (2012). Akuntansi Biaya. Graha Ilmu. Yogyakarta.

William Carter. (2012). Akuntansi Biaya. Edisi Keempatbelas. Salemba Empat. Jakarta. 